\title{
Seven years of biochar amendment has a negligible effect on soil available $P$ and a progressive effect on organic $C$ in paddy soils
}

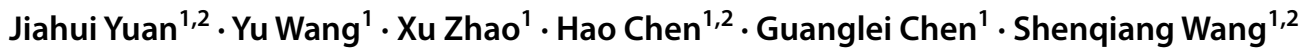

Received: 9 June 2021 / Accepted: 3 November 2021

(c) The Author(s) 2022

\begin{abstract}
Little attention has been paid to how long-term application of crop straw and its biochar affects soil phosphorus (P) transformation and carbon $(\mathrm{C})$ fractions. We conducted a 7-year field experiment including control treatment (chemical fertilizer only, $\mathrm{CK})$, straw return $\left(2.25 \mathrm{t} \mathrm{ha}^{-1}\right)$, and different amounts of biochar addition $\left(11.25 \mathrm{t} \mathrm{ha}^{-1}(0.5 \% \mathrm{BC})\right.$ and $22.5 \mathrm{tha}^{-1}(1.0 \% \mathrm{BC})$, to investigate influence of these amendments on soil $\mathrm{C}$ structure, $\mathrm{P}$ fractions, and their interaction with microorganisms. The ${ }^{13} \mathrm{C}$ nuclear magnetic resonance and soil $\mathrm{P}$ sequence fractionation were applied to capture changes of soil $\mathrm{C}$ compositions and $\mathrm{P}$ pool. Compared to $\mathrm{CK}$, straw and biochar amendments decreased alkyl C/O-alkyl C, which is conducive to increased soil organic $\mathrm{C}$. The $0.5 \% \mathrm{BC}$ and $1.0 \% \mathrm{BC}$ treatments enhanced recalcitrant aromatic $\mathrm{C}$ by $69.0 \%$ and $131 \%$, respectively. Compared to $\mathrm{CK}\left(101.2 \pm 33.32 \mathrm{mg} \mathrm{kg}^{-1}\right)$, the $0.5 \% \mathrm{BC}$ and $1.0 \% \mathrm{BC}$ treatments had a negligible effect on soil available $\mathrm{P}$, while negative effects were observed in straw treatment $\left(59.79 \pm 9.023 \mathrm{mg} \mathrm{kg}^{-1}\right)$. Straw and biochar amendments increased primary $\mathrm{P}$ and occluded $\mathrm{P}$, whereas had negligible effect on organic $\mathrm{P}$. Redundancy analysis and correlation analysis indicated that $\mathrm{C}$ compositions and $\mathrm{P}$ pool correlated to microbial community composition and enzyme activities, and aromatic $\mathrm{C}$ was the most related factor. Moreover, structural equation modeling indicated available $\mathrm{P}$ was most related to phosphatase activity and $\mathrm{C}$ composition. Our findings reveal the changes of soil $\mathrm{P}$ and $\mathrm{C}$ response under long-term crop straw and its biochar amendment, and can contribute toward improving understanding of the effect of biochar and straw return in future agriculture management.
\end{abstract}

\section{Highlights}

Seven-year biochar amendment favored SOC by increasing aromatic C. Available P varied little in biochar amendment but reduced under straw treatment. Aromatic $\mathrm{C}$ was the dominant factor for variations in microorganisms. Available $\mathrm{P}$ was most related to phosphatase activity and $\mathrm{C}$ composition.

Keywords Biochar $\cdot$ Paddy soil $\cdot$ Soil phosphorus fractionation $\cdot$ Carbon composition $\cdot$ Microorganisms

\section{Introduction}

Yu Wang

wangyu@issas.ac.cn

$\triangle$ Shenqiang Wang

sqwang@issas.ac.cn

1 State Key Laboratory of Soil and Sustainable Agriculture, Changshu National Agro-Ecosystem Observation and Research Station, Institute of Soil Science, Chinese Academy of Sciences, Nanjing 210008, China

2 University of the Chinese Academy of Sciences, Beijing 10049, China
The return of crop residues to the field is a direct and effective way to recycle resources, improve soil nutrient cycling, and increase crop yields (Jiang et al. 2019). Incorporating biochar formed by pyrolysis of crop residues into the soil has been proposed as an attractive strategy for increasing soil carbon (C) sequestration and improving soil fertility (Dong et al. 2018; Glaser and Lehr 2019; Majumder et al. 2019; Zhang et al. 2020). Owing to the difference in carbon content and stability of crop straw and its biochar, longterm application of crop straw and its biochar may change the concentration and composition of soil organic carbon (SOC). Exploration of the response of SOC composition 
and the underlying mechanisms to crop residues and biochar amendments is critical for understanding $\mathrm{C}$ cycling.

The chemical structure of SOC itself has huge difference with soil types, which plays a vital role in its stability. The increase in the intensity of aromatic $\mathrm{C}$ after high-temperature pyrolysis of biochar contributes to improvement of SOC (Liu et al. 2016; Bi et al. 2020). Regarding the applied biochar and the bulk soil as whole integrity, the analysis of the overall chemical structure is helpful for in-depth study of the changes in SOC. Soil microbial community and enzyme activities respond sensitively to changes in SOC structure (Liu et al. 2019; Wei et al. 2019). Not only the amount of SOC, but the C composition is also closely related to the microbial community composition and activity ( $\mathrm{Ng}$ et al. 2014). The improvement of soil physicochemical properties and introduction of $\mathrm{C}$ by biochar application can regulate the compositions, capacities, and functions of soil microorganisms (Palansooriya et al. 2019). The gram-negative bacteria prefer to exploit simple C groups (Holding 1960), which contributes to the promotion of recalcitrant $\mathrm{C}$, especially aromatic C components. Similarly, Chen et al. (2019a) described that aromatic $\mathrm{C}$ was positively correlated to the $\mathrm{G}^{+}$bacteria abundance and 63: was an important factor in shaping composition of the main microbial groups and improving enzyme activities. Biochar application was shown to enhance the network structure stability of rhizosphere bacteria (Huang et al. 2019). In addition, soil enzymes are closely related to the transformation and mineralization of SOC (Sinsabaugh 2010). Wang et al. (2017) demonstrated that soil alkyl $\mathrm{C}$ and ketone $\mathrm{C}$ are the main influencing factors of enzyme activities, rather than $\mathrm{C}$ quantity. Most oxidoreductases have the ability to decompose recalcitrant C. Chen et al. (2019a) illustrated positive correlations between phenol oxidase and aromatic $\mathrm{C}$, and the increase in $\mathrm{pH}$ caused by the amendment of biochar also contributed to the increase of enzyme activities. Crop straw and biochar amendments may alter the chemical composition and decomposition degree of SOC, resulting in variations of soil microbial diversity and community structure. However, few studies have focused on changes in soil $\mathrm{C}$ structure and its feedback on microbial composition and enzyme activity, especially under long-term straw and biochar application (Chen et al. 2019a, b).

The mobilization and immobilization processes of soil $\mathrm{P}$ were intricate, and the regulation of soil $\mathrm{P}$ dynamics could be accomplished by changes to soil $\mathrm{pH}$ (Xu et al. 2018), the adsorption-desorption balance (Xu et al. 2014; Borno et al. 2018), and microorganism communities (Mitchell et al. 2015; Palansooriya et al. 2019). The influence of biochar application on soil phosphorus (P) availability is not consistent under different experimental conditions and durations (Anderson et al. 2011; Biederman and Harpole 2013; Ngatia et al. 2017). Meta-analysis results for short-term pot or incubation researches have described that biochar amendment mainly increases soil available P level with a large range of characteristics and application rates of biochar, soil types, or experimental conditions, whereas it is inclined to remain little change under field experiments, particularly in long-term studies (Gao et al. 2019; Glaser and Lehr 2019). The increasing effect was mainly attributed to decreased soil acid and increased alkaline phosphatase enzyme activities and P-solubilizing bacteria (Zhou et al. 2020). Biochar can be used as a source of $P$ to provide soluble and exchangeable $\mathrm{P}$ to soil, and it can also increase the availability of endogenous $\mathrm{P}$ by affecting the complexation and metabolic effects related (Yang et al. 2021). However, the negative results were attributed to the strong adsorption capacity of biochar (Borno et al. 2018). Biochar can also directly or indirectly affect the availability of $\mathrm{P}$ by affecting crop $\mathrm{P}$ uptake and soil $\mathrm{P}$ loss process (Yang et al. 2021). Moreover, soil microorganisms and extracellular enzymes play critical roles in transformation of soil P forms (Richardson and Simpson 2011; Liang et al. 2017), which can be altered by crop straw and biochar amendment. Applying biochar to soil can change the secretion of protons and organic acids and disturb the activity of soil phosphatase by affecting the diversity and activity of microorganisms, thereby affecting the conversion of soil P (Yang et al. 2021). The application of biochar may also affect the microbial community through the provision of microbial niche environment ( $\mathrm{Lu}$ et al. 2020) and the change of soil pH. Exploration of relationship between microbial community composition, enzyme activities and $\mathrm{P}$ pools is important for clarifying the variations of soil $\mathrm{P}$ availability under long-term amendment with crop straw and its biochar.

The microorganisms are the linkage between soil $\mathrm{C}$ composition and P pools. Jing et al. (2017) indicated that adding labile $\mathrm{C}$ to soil may favor soil $\mathrm{P}$ availability by increasing microbial turnover. Revealing relationships between soil C composition and $\mathrm{P}$ availability as well as associated microorganisms, in addition to the potential underlying mechanism, is crucial for understanding the particularity of $\mathrm{P}$ cycling dynamic (Reed et al. 2015) in straw and biochar amended soils. It is therefore necessary to investigate the influence of soil C composition on microbial species and their functions, in addition to $\mathrm{P}$ dynamics after straw and biochar application to promote environmental sustainability of straw and biochar application (Ayaz et al. 2021; Pan et al. 2021), especially through long-term field experiments.

Therefore, based on long-term rice-wheat rotation field experiments in the Taihu Lake region focusing on amendment with crop straw and its biochar, we investigated the response of microbial-mediated morphological variations of soil $\mathrm{C}$ composition and $\mathrm{P}$ pools during the wheat season in the seventh year. Our objectives were (i) to investigate 
the influence of crop straw and biochar amendment on soil $\mathrm{C}$ structure; (ii) to observe the changes of various soil $\mathrm{P}$ pools; and iii) to characterize the variations in microbial community and enzyme activity dynamics affected by soil $\mathrm{C}$ composition and $\mathrm{P}$ speciation. We hypothesis that crop straw and biochar amendments will improve the availability of soil P and the stability of SOC structure, and increase the activity of microorganisms and enzymes.

\section{Materials and methods}

\subsection{Field experiments}

The field experiment was carried out at Yixing Agro-Environment Research Base, the National Agroecosystem Observatory and Research Station of Changshu (YX, 119 $54^{\prime} \mathrm{E}$, $\left.31^{\circ} 16^{\prime} \mathrm{N}\right)$. The field was located about $1 \mathrm{~km}$ northwest of Taihu Lake, which is a typical rice-wheat cropping region. Four different treatments with three replicates included chemical fertilizer with no biochar (control; CK), chemical fertilizer with $11.3 \mathrm{t} \mathrm{ha}^{-1}$ biochar $(0.5 \% \mathrm{BC})$, chemical fertilizer with $22.5 \mathrm{t} \mathrm{ha}^{-1}$ biochar $(1.0 \% \mathrm{BC})$, and chemical fertilizer with $2.25 \mathrm{t} \mathrm{ha}^{-1}$ crop straw (Straw) for each crop season. The experiment was set up in June 2010 from the beginning of rice-growing season. As rice transplanted inflooded soil after successive straw incorporation often grows and yields poorly (Zhao et al. 2014), therefore, the straw returning treatment adopted was at a level of $2.25 \mathrm{t}$ $\mathrm{ha}^{-1}$ per crop season, which was equal to its carbonized mass. The plots under four practices were randomly allocated among the field. The biochar prepared from crop straw (pyrolysis at $500^{\circ} \mathrm{C}$ for $8 \mathrm{~h}$ ) was applied to the topsoil $(0-20 \mathrm{~cm})$. Chemical fertilizer application rates were consistent across all treatments. P fertilizer applied for per season was $60 \mathrm{~kg} \mathrm{P}_{2} \mathrm{O}_{5} \mathrm{hm}^{-2}$. The urea application dose was $250 \mathrm{~kg} \mathrm{~N} \mathrm{hm}^{-2}$ (ratio 3:4:3 was applied basally, at tillering stage and jointing stage). The potassium application dose was $60 \mathrm{~kg} \mathrm{~K}_{2} \mathrm{O} \mathrm{hm}^{-2}$. Soil samples were collected during the 2017 wheat harvest season. Soil samples were air-dried and sieved $(2 \mathrm{~mm})$ prior to further analysis. Basic physical and chemical properties of collected soil samples were shown in Table 1.

\subsection{Carbon-13 nuclear mass resonance spectroscopy}

In this study, ${ }^{13} \mathrm{C}$ nuclear magnetic resonance (NMR) spectroscopy was used to observe soil $\mathrm{C}$ compositions. Soil samples were first processed with $10 \% \mathrm{HF}$ for eight times and hydrogen peroxide for four times. ${ }^{13} \mathrm{C}$ of subsamples was analyzed through Bruker Avance 400 (Bruker BioSpin, Rheinstetten, Germany) with a resonance frequency of $100 \mathrm{MHz}$. We adjusted the contact time of $1000 \mu$ s, the relaxation time of $0.5 \mathrm{~s}$, and the combination of ramp contact mode and 64-step small phase increment alternately (SPINAL64) to decouple the pulse program. (Wang et al. 2017). Soil C compositions were calculated by corresponding chemical shift values of the spectra according to Shrestha et al. (2015). Details were expressed as follows: alkyl C (0-45 ppm), O-alkyl C (45-110 ppm), aromatic C (110-160 ppm), and carbonyl C (160-220 ppm) (Shen et al. 2018). The ratios of soil alky C/O-alkyl C (A/O-A) and Aromatic $\mathrm{C} /($ alkyl $\mathrm{C}+\mathrm{O}$-alkyl $\mathrm{C}+$ aromatic $\mathrm{C})$ (Aromaticity) and (alkyl $\mathrm{C}+$ aromatic $\mathrm{C}) /(\mathrm{O}$-alkyl $\mathrm{C}+$ carbonyl $\mathrm{C})(\mathrm{HI})$ were considered indicators of decomposition degree, complexity and hydrophobicity of SOC (Shen et al. 2018; Zhang et al. 2019; Xu et al. 2020).

\subsection{Soil P fractionation}

The Tiessen and Moir (1993) fractionation method modified by Wang et al. (2016) was used to analyze the soil P level during the seventh year of the wheat harvesting stage. Soil samples were processed sequentially as follows: addition of deionized water with one resin strip (Sinopharm Chemical Reagent Co., Ltd); $0.5 \mathrm{M} \mathrm{NaHCO}_{3}$ (pH 8.5); $0.1 \mathrm{M} \mathrm{NaOH}$; $1 \mathrm{M} \mathrm{HCl}$; and $\mathrm{H}_{2} \mathrm{SO}_{4}$ and $\mathrm{H}_{2} \mathrm{O}_{2}$ digested at $360^{\circ} \mathrm{C}$. The extraction process was reciprocated for $16 \mathrm{~h}$ followed by centrifugation and filtration through a $0.42 \mu \mathrm{m}$ pore size filter membrane. The $\mathrm{NaHCO}_{3}$ and $\mathrm{NaOH}$ extractions were divided into two portions to quantify contents of total $\mathrm{P}$ and inorganic $\mathrm{P}(\mathrm{Pi})$. Pi amounts were measured directly, and total $\mathrm{P}$ was measured after the digestion. The difference between total $\mathrm{P}$ and $\mathrm{Pi}$ above-mentioned was calculated as soil organic $\mathrm{P}(\mathrm{Po})$. Soil $\mathrm{P}$ concentrations were measured based on ascorbic acid molybdenum blue method (Murphy and Riley 1962) using an ultraviolet spectrometer (UV 2500
Table 1 Basic physical and chemical properties of collected soil samples

\begin{tabular}{lllll}
\hline & $\mathrm{pH}$ & $\mathrm{SOC}\left(\mathrm{g} \mathrm{kg}^{-1}\right)$ & $\mathrm{TP}\left(\mathrm{mg} \mathrm{kg}^{-1}\right)$ & Olsen-P $\left(\mathrm{mg} \mathrm{kg}^{-1}\right)$ \\
\hline $\mathrm{CK}$ & $5.50 \pm 0.08 \mathrm{c}$ & $13.81 \pm 1.65 \mathrm{~d}$ & $632.7 \pm 50.17 \mathrm{~b}$ & $47.09 \pm 15.82 \mathrm{a}$ \\
$0.5 \% \mathrm{BC}$ & $6.26 \pm 0.15 \mathrm{~b}$ & $32.39 \pm 3.22 \mathrm{~b}$ & $622.8 \pm 52.44 \mathrm{~b}$ & $36.75 \pm 6.01 \mathrm{ab}$ \\
$1.0 \% \mathrm{BC}$ & $6.70 \pm 0.06 \mathrm{a}$ & $39.87 \pm 2.89 \mathrm{a}$ & $734.4 \pm 50.78 \mathrm{a}$ & $52.30 \pm 2.72 \mathrm{a}$ \\
Straw & $6.18 \pm 0.06 \mathrm{~b}$ & $18.86 \pm 1.47 \mathrm{c}$ & $535.8 \pm 16.71 \mathrm{~b}$ & $26.41 \pm 3.97 \mathrm{~b}$ \\
\hline
\end{tabular}

$S O C$ soil toal carbon, $T P$ total phosphorus 
Japan). Each component can represent a specific $\mathrm{P}$ pool (Hou et al. 2016). Specifically, Resin-P and $\mathrm{NaHCO}_{3}$-Pi were considered as available $\mathrm{P}$ that can be easily taken up by plants. $\mathrm{NaHCO}_{3}$-Po and NaOH-Po represented an organic $\mathrm{P}$ pool. $\mathrm{NaOH}-\mathrm{Pi}$ was accounted for secondary mineral $\mathrm{P}$ with poor availability. HCl-P was considered as primary mineral $\mathrm{P}$ which is bound with calcium and released by the weathering process. Residual $\mathrm{P}$ represented occluded $\mathrm{P}$ that had the lowest availability because of its particularly low solubility.

\subsection{PLFAs analysis}

Soil microbial community compositions were analyzed by measuring soil phospholipid fatty acid (PLFA) concentrations. Bligh-Dyer extract $\left(\mathrm{V}_{\text {Chloroform }}\right.$ : $\mathrm{V}_{\text {methanol }}$ : $\mathrm{V}_{\text {citrate buffer }}=1: 2: 0.8$ ) was used for extraction of the lyophilized soil lipids (Frostegard et al. 1993; Wang et al. 2016). Acetone, chloroform and methanol were sequentially added to Supelclean ${ }^{\mathrm{TM}}$ Solid Phase Extraction Tubes to finally purify the phospholipid component in the sample. After saponification, methylation and extraction steps, the sample to be tested was dissolved out with n-hexane for determination. The obtained samples were isolated and distinguished on a gas chromatograph (Agilent $7890 \mathrm{~N}$, Wilmington, DE) equipped with a MIDI Sherlock microbial identification system (Version 4.5, MIDI, Newark, NJ). The specific PLFAs abundance was calculated from the response value of the 19:0 methyl nonadecanoate standard.

Soil microbial compositions were identified based on their specific PLFA biomarkers. The sum of i14:0, i15:0, a15:0, i16:0, i17:0, and a17:0 was the indicator for grampositive $\left(\mathrm{G}^{+}\right)$bacteria; 16:1w7c, 18:1w7c, cy17:0, and cy 19:0 for gram-negative $\left(\mathrm{G}^{-}\right)$bacteria; 10Me16:0, 18:2w6c and 18:1w9c for fungi; and 16:1w5c for AMF (Frostegard et al. 1993; Zelles 1999; Bowles et al. 2014). Soil bacteria were the sum of $\mathrm{G}^{+}, \mathrm{G}^{-}, 15: 0$ and 17:0.

\subsection{Microbial activities}

Nine hydrolases and oxidoreductases associated with soil $\mathrm{P}$ and $\mathrm{C}$ cycles were measured. Soil acid phosphatase (ACP), alkaline phosphatase (ALP), and $\beta$-glucosidase ( $\beta$-GC) activities were calculated from the content of p-nitrophenol produced by the hydrolysis of different substrates (Tabatabai 1994; Eivazi and Tabatabai 1988). Nitrate reductase (NR) was determined by identifying the absorbance of red azo compounds (Guan 1986). Soil sucrase (SC) and urease (UE) activities were measured based on sodium thiosulfate titration and indophenol blue colorimetry method (Guan 1986). Cellulase (CL) activity was determined with anthrone colorimetry method (Deng and Tabatabai 1994). Catalase activity (CAT) was calculated by amount of $\mathrm{O}_{2}$ evolved and polyphenol oxidase (PPO) activity was measured by colored substances produced by catalytic pyrogallol (Montgomery and Sgarbieri 1975). The geometric mean of enzyme activity (Gmea), hydrolase (GH) and oxidoreductase (GOR) activities were calculated as followed.

Gmea $=\sqrt[9]{\mathrm{ACP} \times \mathrm{GC} \times \mathrm{CAT} \times \mathrm{NR} \times \mathrm{UE} \times \mathrm{SC} \times \mathrm{CL} \times \mathrm{PPO}}$

$\mathrm{GH}=\sqrt[6]{\mathrm{ACP} \times \mathrm{ALP} \times \beta-\mathrm{GC} \times \mathrm{UE} \times \mathrm{SC} \times \mathrm{CL}}$

$\mathrm{GOR}=\sqrt[3]{\mathrm{CAT} \times \mathrm{NR} \times \mathrm{PPO}}$

\subsection{Calculations and statistical analysis}

The influence of straw and biochar amendments on soil parameters was tested using the Duncan method $(P<0.05)$ and one-way ANOVA by SPSS 17.0. Relationships between $\mathrm{C}$ compositions PLFAs and enzyme activities, and $\mathrm{P}$ pools PLFAs and enzyme activities were analyzed by redundancy analysis (RDA) using Canoco 4.5. Pearson correlation analysis explored the linear relationship between $\mathrm{C}$ compositions, $\mathrm{P}$ pools, PLFAs and enzyme activities. Structural equation modeling (SEM) was employed to reveal the possible path for the potential underlying microbial mechanisms on available P under biochar and straw amendments altered SOC. In order to obtain the indexes characterizing microbial community compositions, enzyme activities, and soil C compositions, respectively, we averaged the Z-scores of PLFAs, phosphatase, and the relative abundance of functional groups using the function in vegan package. Adequate models were evaluated by $\chi^{2}$ test ( $\chi^{2} / \mathrm{df}<2 ; P>0.05$ ), goodnessof-fit index (GFI $>0.9)$, and a low root-mean-square error of approximation (RMSEA) $(P<0.05)$. The SEM analyses were conducted by AMOS 22.0 (IBM Corporation 2013). The correlation diagram and Z-score calculation were performed through $\mathrm{R}$ version 3.6.1.

\section{Results}

\subsection{Relative abundance of $C$ composition}

The relative abundance and values of major $\mathrm{C}$ compositions are provided in Fig. 1. In the seventh wheat-harvesting season, the order of relative proportions of $\mathrm{C}$ compositions was O-alkyl C > alkyl C > aromatic C > carbonyl C (Fig. 1a). Soil aromatic $\mathrm{C}$ proportion increased along with biochar dose, which resulted in a decreasing trend in O-alkyl $\mathrm{C}$ and alkyl C. Soil aromaticity intensity increased by $68.7 \%$ and $132 \%$ at the two biochar dosages, and the ratio of A/O-A decreased by $5.5 \%$ and $11.2 \%$, respectively (Fig. 1c, d). For the Straw 

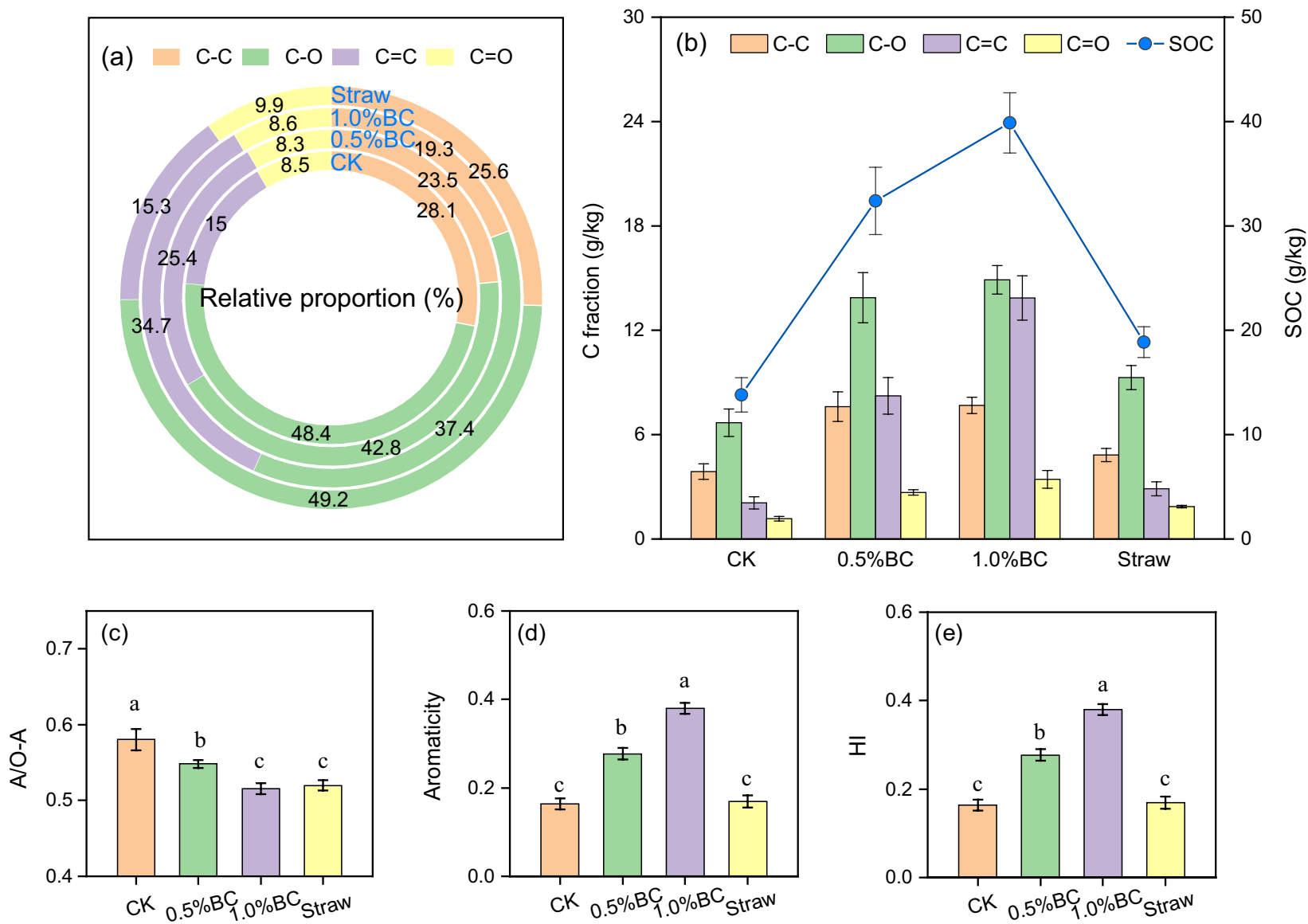

Fig. 1 The relative proportion (\%) and value of shift regions of ${ }^{13} \mathrm{C}$ CPMAS NMR spectra and $\mathrm{C}$ quality index in paddy soil during the wheat-growing season under different fertilization treatments. Four different fertilizer practices were no biochar (control, CK); $11.3 \mathrm{Mg} \mathrm{ha}^{-1}$ biochar (0.5\%BC); $22.5 \mathrm{Mg} \mathrm{ha}^{-1}$ biochar (1.0\%BC); and $2.25 \mathrm{Mg} \mathrm{ha}^{-1}$ crop straw (Straw) amended for each crop season.

treatment, the relative intensity of alkyl C enhanced by $8.9 \%$, and the ratio of $\mathrm{A} / \mathrm{O}-\mathrm{A}$ decreased by $10.4 \%$ compared with chemical fertilization. The content of each soil $\mathrm{C}$ fraction was calculated by multiplying the proportions and the corresponding SOC concentration. As the amendment with straw and its biochar significantly increased SOC concentration compared to $\mathrm{CK}$, the absolute amount of all $\mathrm{C}$ fractions increased significantly (Fig. 1b).

\subsection{Changes in soil $P$ fractionation}

The soil total $\mathrm{P}$ fraction ranged from 532.5 to $760.8 \mathrm{mg} \mathrm{kg}^{-1}$ and was highest under the $1.0 \% \mathrm{BC}$ amendment and lowest under the Straw treatment (Fig. 2). Compared with the $\mathrm{CK}$ treatment, the $0.5 \% \mathrm{BC}$ and $1.0 \% \mathrm{BC}$ biochar applications decreased soil secondary mineral $\mathrm{P}$ concentration by $39.2 \%$ and $42.0 \%$, respectively, but elevated soil occluded
$\mathrm{C}-\mathrm{C}, \mathrm{C}-\mathrm{O}, \mathrm{C}=\mathrm{C}$, and $\mathrm{C}=\mathrm{O}$ are symbolic representations of alkyl-C, $\mathrm{O}$-alkyl-C, aromatic-C, and carbonyl-C, respectively. Vertical bars indicate standard deviations of the mean $(n=3)$. For each parameter, different letters indicate significant differences between means at $P<0.05$

P concentration by $24.4 \%$ and $28.9 \%$, respectively. A similar result was captured under the Straw treatment with a $40.9 \%$ decrease in secondary mineral $\mathrm{P}$ and a $14.8 \%$ increase in the occluded P pool. Furthermore, the Straw treatment decreased the concentration of soil available P. However, no significant differences were found in the primary mineral $\mathrm{P}$ pool under $0.5 \% \mathrm{BC}$ biochar and straw amendment compared with CK.

\subsection{PLFA and soil enzyme activities}

Total microbial contents were measured within the 82.28-203.5 $\mu_{\mathrm{g} \mathrm{g}}{ }^{-1}$ range. As shown in Fig. 3, the $0.5 \% \mathrm{BC}, 1.0 \% \mathrm{BC}$, and Straw treatments significantly reduced soil fungal PLFA by $31.6 \%, 45.1 \%$, and $40.6 \%$, respectively. However, bacterial PLFAs did not vary significantly under different treatments, and similar results were obtained in $\mathrm{F} / \mathrm{B}$ and $\mathrm{G}^{+} / \mathrm{G}^{-}$ratio values. Biochar and 

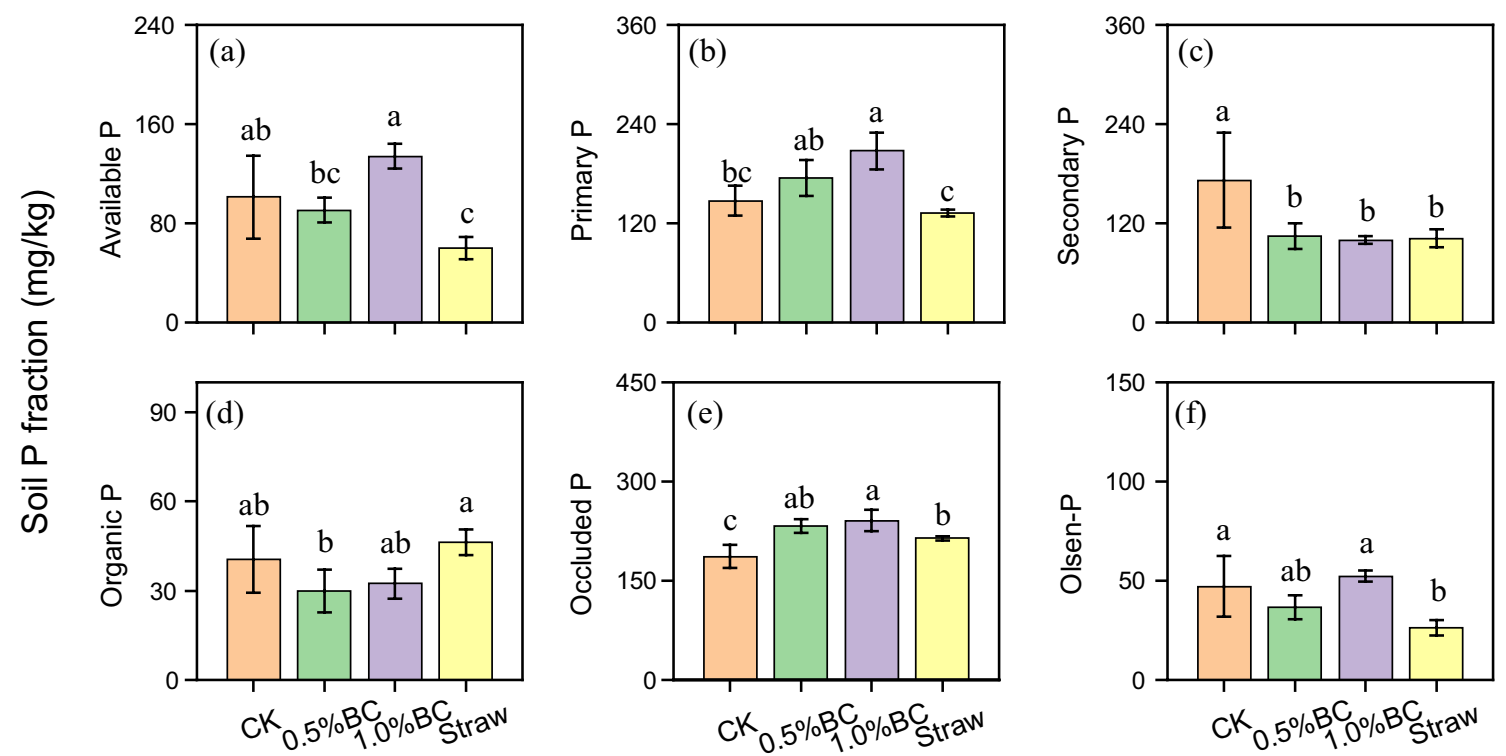

Fig. 2 The sequentially-extracted $\mathrm{P}$ fractions in paddy soil during the wheat-growing season under different fertilization treatments. Four different fertilizer practices were no biochar (control, CK); 11.3 $\mathrm{Mg} \mathrm{ha}{ }^{-1}$ biochar $(0.5 \% \mathrm{BC}) ; 22.5 \mathrm{Mg} \mathrm{ha}^{-1}$ biochar (1.0\% BC); and $2.25 \mathrm{Mg} \mathrm{ha}^{-1}$ crop straw (Straw) amended for each crop season. Vertical bars indicate standard deviations of the mean $(n=3)$. For each parameter, different letters indicate significant differences between means at $P<0.05$
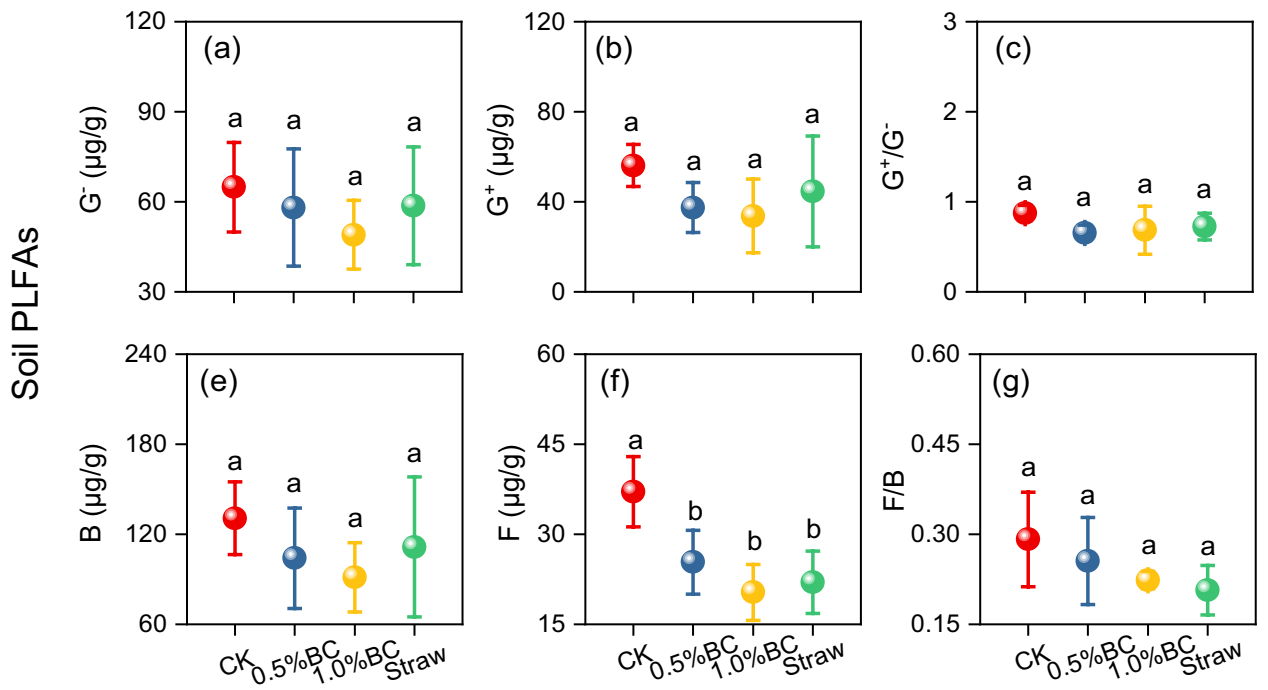

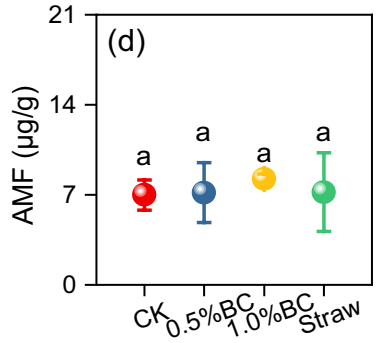

Fig. 3 Phospholipid fatty acid (PLFA) concentrations in paddy soil during the wheat-growing season under different fertilization treatments. Four different fertilizer practices were no biochar (control, CK); $11.3 \mathrm{Mg} \mathrm{ha}^{-1}$ biochar (0.5\%BC); $22.5 \mathrm{Mg} \mathrm{ha}^{-1}$ biochar

straw amendments for seven years significantly facilitated soil enzyme activities based on increased Gmea, GH, and GOR geometric means (Fig. 4). The treatment of returning straw back to field had a strong promotion effect on enzyme activity. However, biochar amendment reduced
(1.0\%BC); and 2.25 $\mathrm{Mg} \mathrm{ha}^{-1}$ crop straw (Straw) amended for each crop season. Vertical bars indicate standard deviation of the mean $(n=3)$. For each parameter, different letters indicate significant differences between means at $P<0.05$

soil ACP and NR activities $(P<0.05)$ with the higher application amount, suggesting a strong inhibitory effect. CL and PPO were the two most active enzymes among nine measured enzymes, with the highest values under the 

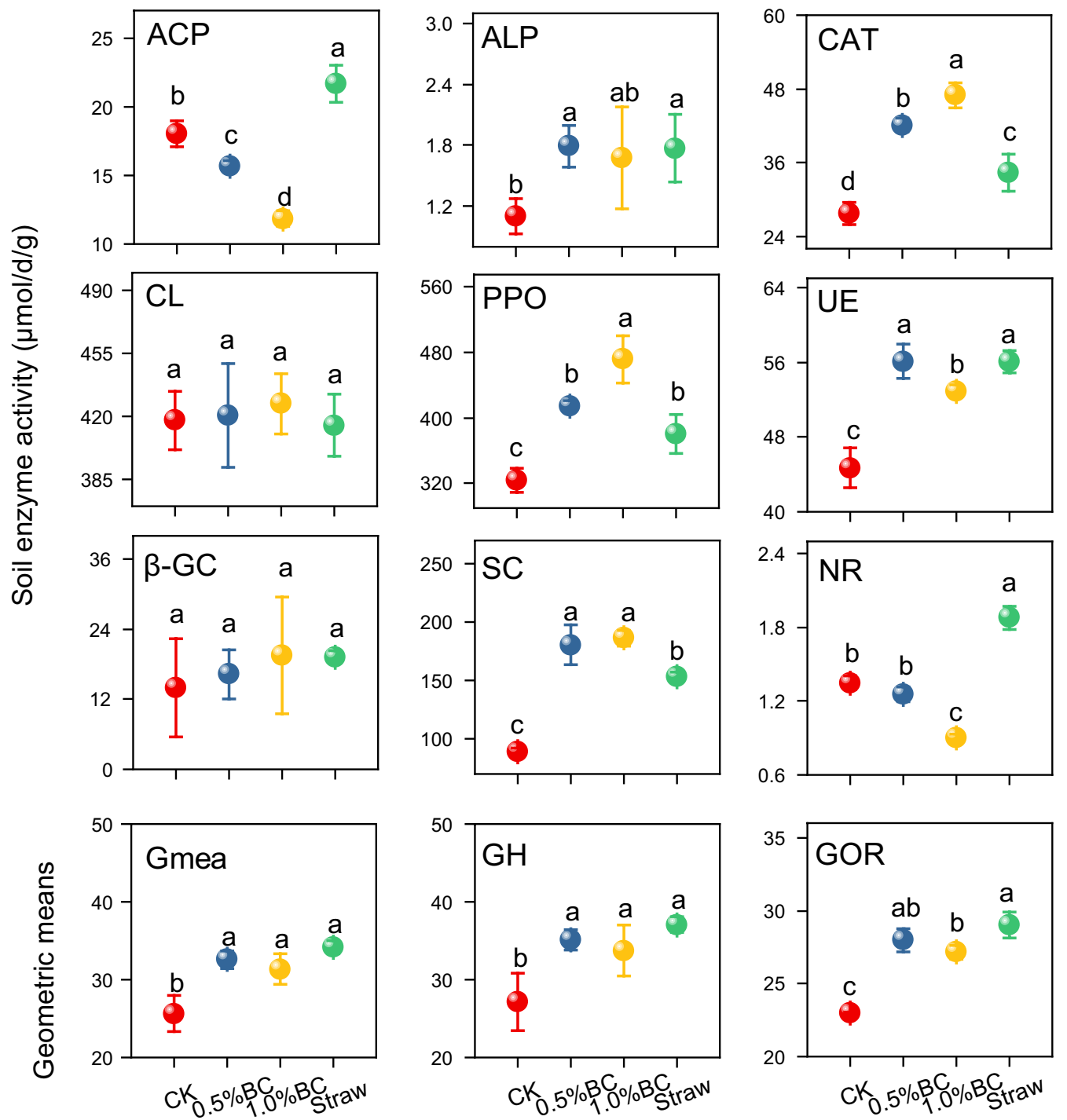

Fig. 4 Soil microbial enzyme activities and the geometric means of the assayed enzyme activities from soil under four fertilization treatments. Four different fertilizer practices were no biochar (control, CK); $11.3 \mathrm{Mg} \mathrm{ha}^{-1}$ biochar $(0.5 \% \mathrm{BC}) ; 22.5 \mathrm{Mg} \mathrm{ha}^{-1}$ biochar (1.0\% BC); and $2.25 \mathrm{Mg} \mathrm{ha}^{-1}$ crop straw (Straw) amended for each

$1.0 \% \mathrm{BC}$ treatment with the activities of $427.1 \pm 16.80$ and $471.8 \pm 28.60 \mu \mathrm{mol} \mathrm{g}^{-1} \mathrm{~d}^{-1}$, respectively.

\subsection{Linking PLFA and soil enzyme activities to $C$ compositions}

In ordination space of soil $\mathrm{C}$ compositions and PLFA, more than $32 \%$ of the variation can be explained by the first RDA axis (Fig. 5a). Soil microbial compositions were positively related to aromatic $\mathrm{C}$, whereas a negative relation was captured with alkyl C. Pearson correlation analysis showed that A/O-A ratio significantly facilitated fungal PLFA and further positively affected the $\mathrm{F} / \mathrm{B}$ ratio value $(P<0.05)$. crop season. Gmea, GH, GOR are symbolic representations of all enzymes, hydrolases, and oxidoreductases. Vertical bars indicate standards deviation of the mean $(n=3)$. For each parameter, different letters indicate significant differences between means at $P<0.05$

Relationships between the $\mathrm{C}$ compositions and enzyme activities were showed in Fig. 5c. More than 85\% variations of enzyme activities can be explained by the first axis and $5.4 \%$ was explained by the second axis. Similarly, soil aromatic $\mathrm{C}$ and alkyl $\mathrm{C}$ were the most influential factors, and aromatic $\mathrm{C}$ was positively related to enzyme activities under $1.0 \% \mathrm{BC}$ amendment. As further shown in Pearson correlation analysis, soil aromatic $\mathrm{C}$ content, aromaticity, and hydrophobicity indicated a promoting relationship with CAT, PPO, and SC activities, whereas an inverse relationship was shown with ACP and NR activities. However, soil alkyl C and O-alkyl C proportions showed opposite results for activities of the above enzymes. 

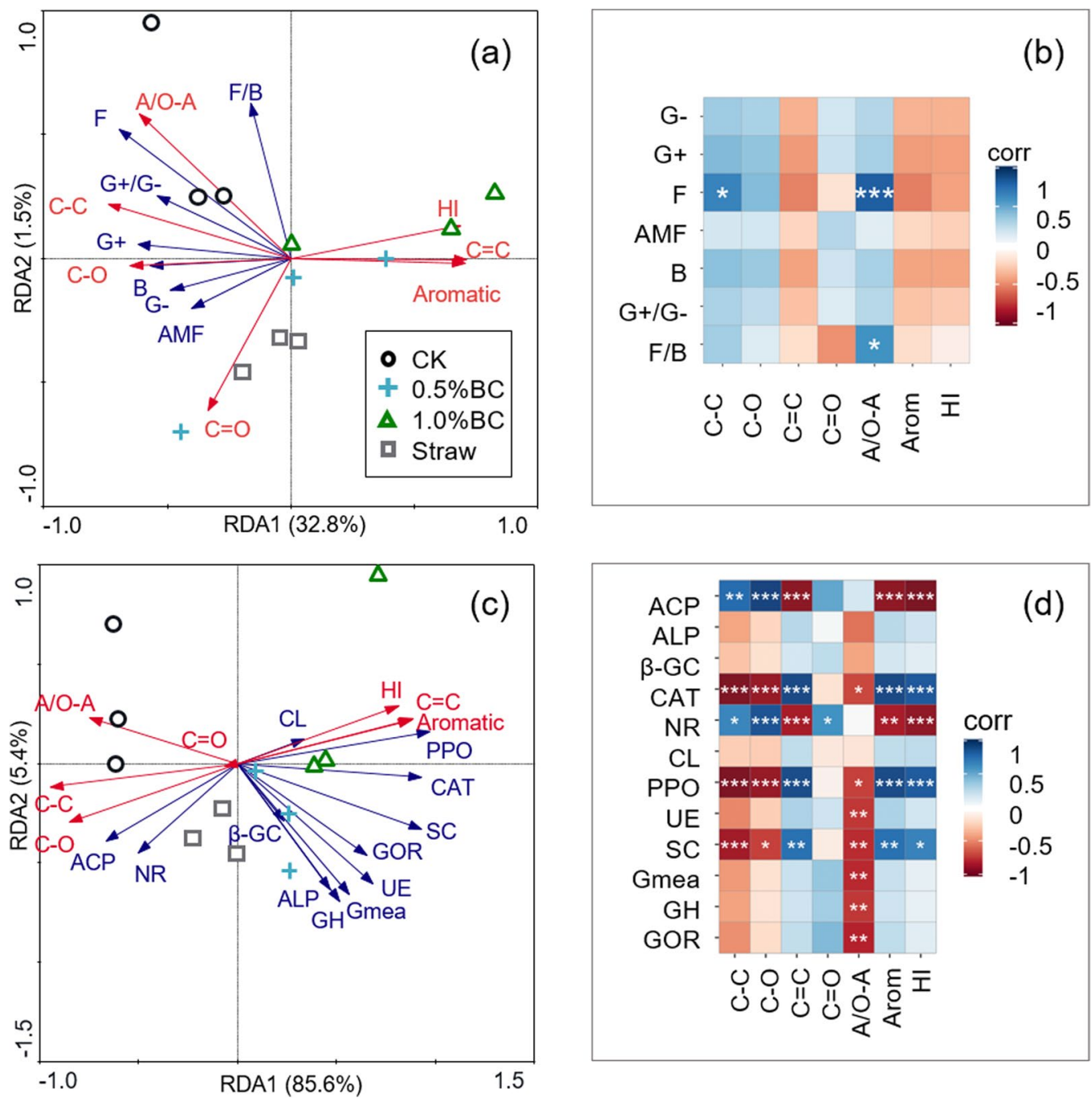

Fig. 5 Redundancy analysis (RDA) and correlation diagram between $\mathrm{C}$ compositions and microorganisms under different fertilization treatments. Figures $\mathrm{a}$ and $\mathrm{b}$ were RDA and correlation diagrams between $\mathrm{C}$ compositions and microbial community. Figures $\mathrm{c}$ and

\subsection{Linking PLFA and soil enzyme activities to $P$ fractions}

Relationships among P speciation, microbial community compositions, and soil enzyme activities were illustrated by RDA and Pearson correlation analysis (Fig. 6). Soil microbial community compositions and enzyme activities accounted for $69.3 \%$ and $94.3 \%$ of the soil $\mathrm{P}$ variation, respectively. Variations in $\mathrm{P}$ fractions were explained more by enzyme activities than by PLFA. Specifically, the fungal PLFA was positively correlated with $\mathrm{NaHCO}_{3}-\mathrm{Po}$ and $\mathrm{NaOH}-\mathrm{Pi}$ and negatively with residual P (Fig. 6b). Similarly, positive and high correlations were also observed between the $\mathrm{F} / \mathrm{B}$ ratio and $\mathrm{NaHCO}_{3}-\mathrm{Pi}$ and $\mathrm{NaOH}-\mathrm{Pi}$ fractions. Moreover, variations in soil $\mathrm{P}$ fractions were more related

$\mathrm{d}$ were RDA and correlation diagrams between $\mathrm{C}$ compositions and enzyme activities. Fitted site scores from the CK, 0.5\%BC, 1.0\%BC, and Straw treatments are displayed by circles, crosses, triangles, and squares, respectively. The red arrows represent $\mathrm{C}$ compositions

to hydrolase activities than oxidoreductases (Fig. 6d), particularly for soil ACP activity.

\subsection{Influence $s$ of biochar and straw amendments on soil available $P$}

The SEM result adequately suited the interaction pathway among SOC, C composition, microbial PLFAs, phosphatase activity, and available $\mathrm{P}$ in response to biochar and straw amendments (Fig. 7). The variation of SOC under biochar and straw amendmenst directly affected the relative intensity of soil C composition, explaining $71 \%$ of the variance. Soil phosphatase activity was negatively related to available $\mathrm{P}$ $\left(R^{2}=64 \%\right)$ (Fig. 7a). Phosphatase was the strongest predictor for soil available $\mathrm{P}$, followed by soil $\mathrm{C}$ composition (Fig. 7b). 

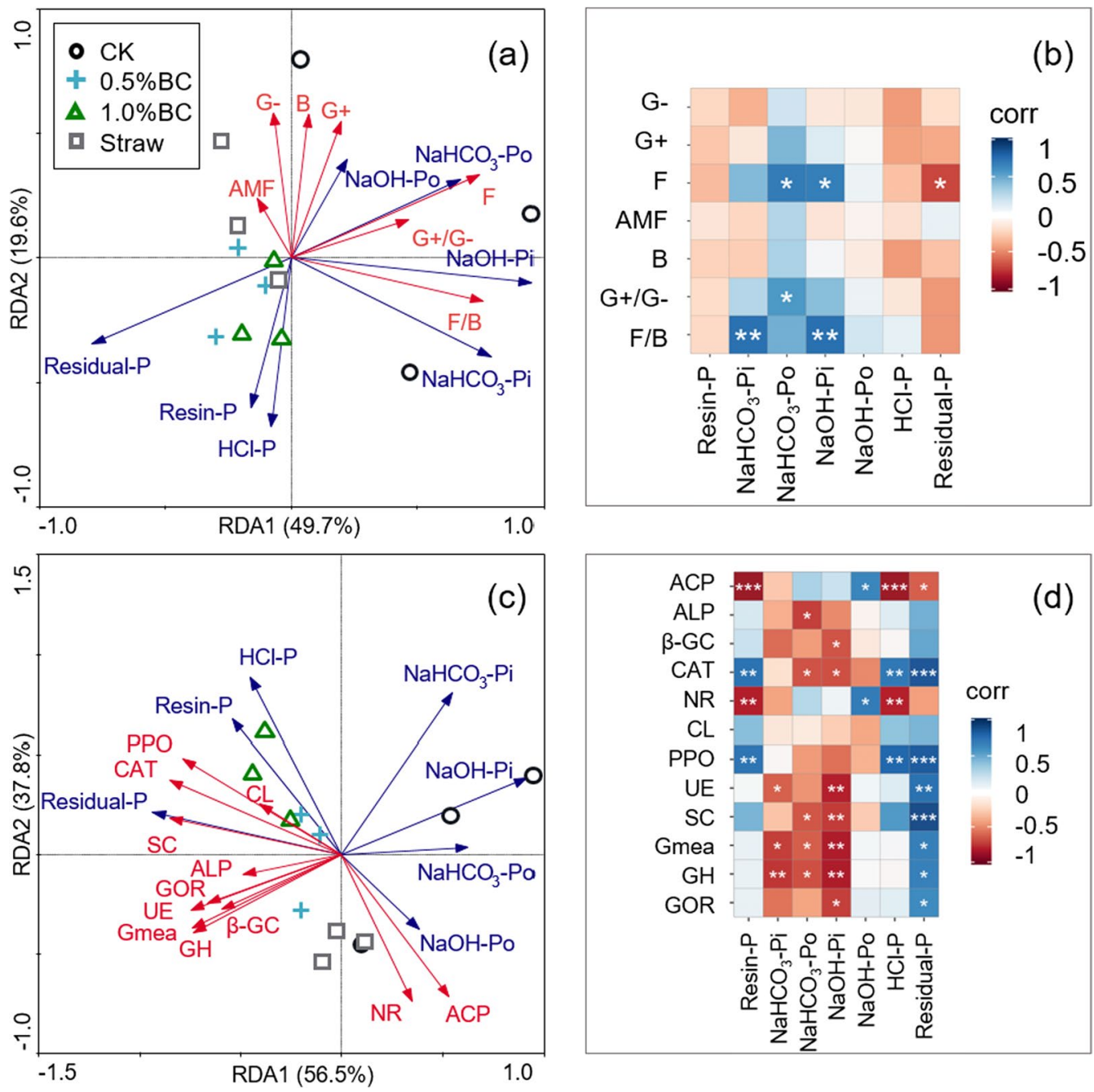

Fig. 6 Redundancy analysis (RDA) and correlation diagram between $\mathrm{P}$ fractions and microorganisms under different fertilization treatments. Figures $\mathrm{a}$ and $\mathrm{b}$ were RDA and correlation diagrams between $\mathrm{P}$ fractions and microbial community. Figures $\mathrm{c}$ and $\mathrm{d}$ were RDA

The pathway of soil phosphatase activity was directly meditated by microbial composition $\left(R^{2}=75 \%\right)$.

\section{Discussion}

\subsection{Soil $C$ quality and $P$ pool responses to straw and biochar application regimes}

For seven-year cropping of this paddy soil, the amendment with biochar had a better effect on the improvement of SOC than straw return, owing to the increase in recalcitrant aromatic $\mathrm{C}$ (Fig. 1). Aromatic $\mathrm{C}$ is usually derived from lignin and tannin that is relatively resistant to decomposition (Baldock et al. 2004). Conjunction with the observation reported by Zhang et al. (2019), physical and biochemical protection and correlation diagrams between $\mathrm{P}$ fractions and enzyme activities. Affected factors are denoted as red arrows and influencing factors are denoted by blue arrows

through aromatic $\mathrm{C}$ within aggregate fractions advanced after maize straw biochar application for five years. Compared to straw, the augmented relative amount of aromatic $\mathrm{C}$ under biochar amendment directly advanced the level of aromaticity intensity and hydrophobicity (the indicator of the $\mathrm{C}$ structure of soil), resulting in higher stability and biological and abiotic degradation (Leng et al. 2019). Compared to CK, straw amendment brought in easily decomposable organic C sources. However, the proportion of decomposition products (mainly alkyl C) in soil was reduced, resulting in low A/O-A ratio and indicating that SOC may be protected by physical and chemical characteristics and not decomposed and utilized by microorganisms (Shrestha et al. 2015). Therefore, although the degree of soil decomposition under the treatment of straw and biochar is similar, the structural 


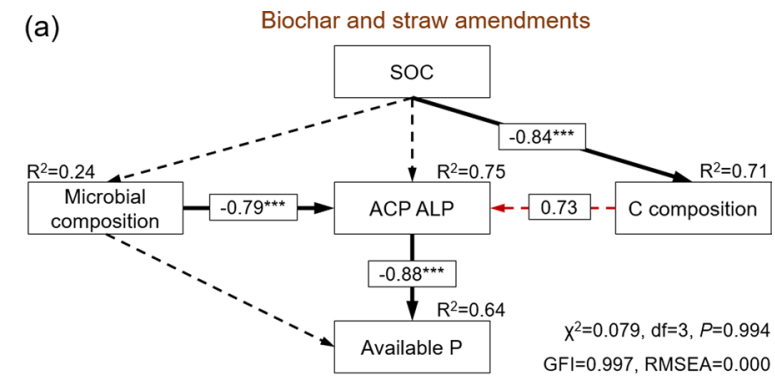

(b)

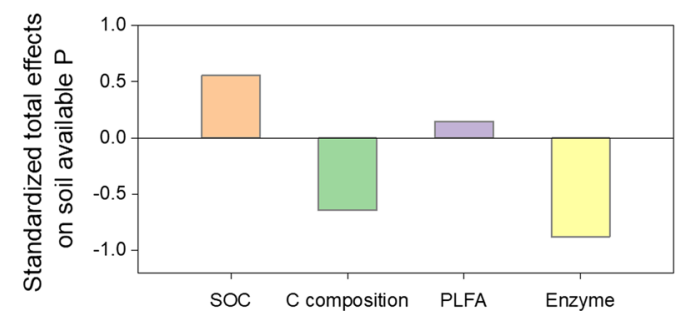

Fig. 7 Structural equation modeling of different factors contributions on soil available $\mathrm{P}$ under biochar and straw amendments (a). The standardized total effects (direct plus indirect effects) were calculated by the structural equation model (b). Numbers on the arrows represent the standardized path coefficients. Black and red arrows indicate significant negative and positive relationships, respectively $(P<0.05)$. Dashed arrows represent the non-significant effects $(P>0.05)$. The provided $R^{2}$ values associated with response variables indicate the proportion of variation explained by relationships with other variables

complexity and stability of biochar are more conducive to the improvement of soil C.

Soil available $\mathrm{P}$ showed no significant variation after seven years in either of the two biochar addition amendments; however, it was significantly reduced under the Straw treatment compared with CK (Fig. 2). A five-year biochar and nitrogen addition field experiment in upland red soil reported that only high-rate biochar increased soil available $\mathrm{P}$ and crop yield, but the effectiveness decreased year by year, and showed a negligible effect during the fifth year (Jin et al. 2019). The introduction of the $P$ source of biochar contributed to the soil primary mineral $\mathrm{P}$ and occluded $\mathrm{P}$ in this study. Schneider and Haderlein (2016) illustrated that the main $\mathrm{P}$ form of pyrolyzed biochar was HCl-P, which represents the less available Ca-P in minerals. The high pyrolysis temperature of biochar helps to accumulate thermally stable carbon (mainly aromatic C). High temperature also leads to a reduction of acidity resulting from the high amount of $\mathrm{Ca}$ and $\mathrm{Mg}$, which promotes the adsorption of $\mathrm{P}$ (Ngatia et al. 2017). The adsorption of P by biochar may be attributed to exchange between solution anions of $\mathrm{P}$ and oxidizing functional group on biochar surface, which can also be provided by volatile organic compounds (Chintala et al. 2014). In addition, the organic $P$ in the raw materials for biochar production gradually converted to inorganic $\mathrm{P}$ with the increasing pyrolysis temperature, which may explain the relative stability in the quantity of organic $\mathrm{P}$ pools observed in this study (Uchimiya et al. 2015; Glaser and Lehr 2019). The results of variations in $\mathrm{P}$ fractions indicated that the amendment with biochar mainly increased the $\mathrm{P}$ that was less available to plants, while had little effect on available $\mathrm{P}$ in wheat season.

\subsection{Influence of straw and biochar amendments on soil phospholipid fatty acids and enzyme activity}

Biochar addition could alter the microbial community composition and enzyme activity by changing soil physicochemical properties. Conflicting with the common results of beneficial effects observed with straw and biochar application on soil microbial community composition (Biederman and Harpole 2013; Yuan et al. 2019), soil fungal biomass decreased in this study (Fig. 3), which indicated that the increased SOC content under straw and biochar amendments may not have provided a sufficient source of available $\mathrm{C}$ for microorganisms in our experiment. The unavailability of $\mathrm{SOC}$ is mainly due to the physical protection of aggregate stability and the chemical stability of clay minerals (Shen et al. 2018; Bi et al. 2020). Furthermore, rich organic-iron complexes in acidic and neutral paddy soils will also reduce the decomposition of labile soil $\mathrm{C}$ by microorganisms (Jones and Edwards 1998). Guo et al. (2020) reported that three months after biochar application, soil microbial community structure and most enzyme activities were significantly increased, and the strongest effect was obtained at a pyrolysis temperature of $300^{\circ} \mathrm{C}$. Soil enzymes can reflect the availability of soil nutrients and microbial activities (Sinsabaugh 2010). The inhibitory effect of biochar treatment on ACP activity increased with the application amount (Fig. 4), which can be attributed to the biochar-induced decrease of soil acidity and enhancement in soil electrical conductivity and salinity (Zhai et al. 2015).

\subsection{Interaction among C compositions, $P$ fractions, and microorganisms}

The patterns of soil PLFAs had important correlations with soil $\mathrm{C}$ fractions as identified with RDA and Pearson correlation analyses, which further highlights the vital role of linking the nature of soil $\mathrm{C}$ with species and functions of the soil microorganisms (Fig. 5). Soil aromatic $\mathrm{C}$ was the main influencing factor to microorganisms. The differences in $\mathrm{C}$ compositions could be mainly attributed to changes in enzyme activity rather than to changes in microbial community compositions as explained by more than $90 \%$ variance in enzyme. According to the correlation graph, the ratio of $\mathrm{A} / \mathrm{O}-\mathrm{A}$ demonstrated a regulatory effect on soil fungal biomass and F/B value, and the increase for aromatic $\mathrm{C}$ 
facilitated soil PPO activity, resulting in a negative correlation with soil O-alkyl-C and alkyl C. Soil PPO had the capacity to degrade more recalcitrant aromatic compounds, and further minimized the toxicity of phenolic molecules (Sinsabaugh 2010). Chen et al. (2019a) also obtained the beneficial effects of aromatic $\mathrm{C}$ on PPO. The significant correlations of aromatic $\mathrm{C}$ with the activities of five enzymes validated that aromatic $\mathrm{C}$ has an important influence on enzyme activity. Our results highlighted the significance of the relationship between $\mathrm{C}$ compositions and soil microbial community compositions and functions. Soil aromatic C had the greatest impact on soil PLFA dynamics and enzyme activity.

Variation in soil microbial community composition regulated changes of $\mathrm{P}$ fraction, particularly for $\mathrm{NaOH}-\mathrm{P}$ fraction with F/B ratio and fungal biomass (Fig. 6), which was mediated by the soil $\mathrm{C}$ composition. Moreover, more than $90 \%$ of variations in $\mathrm{P}$ fractions were related to enzyme activities, particularly with hydrolase enzymes, indicating the vital role in mineralization and decomposition of soil P. Further, SEM results showed that phosphatase activity played an irreplaceable role in elevating available $\mathrm{P}$, and soil $\mathrm{C}$ composition also had an indirect effect (Fig. 7). Different forms of C may affect available $\mathrm{P}$ through the regulation of phosphatase. Soil microbial community composition and enzyme activity are extremely important in SOC decomposition and $\mathrm{P}$ availability regulation. Nevertheless, soil $\mathrm{C}$ chemistry and its interrelations with $\mathrm{P}$ following straw and biochar incorporation still require further research.

\section{Conclusion}

Seven-year biochar amendment favored SOC as a result of the increased recalcitrant aromatic C. Soil available P showed little variation under the biochar amendments, but reduced under the Straw treatment. Both straw and biochar addition increased soil primary $\mathrm{P}$ and occluded P. Soil C composition had a stronger influence on enzyme activities than microbial community composition, and aromatic $\mathrm{C}$ was the dominant component. Pearson correlation analysis illustrated that F/B and ACP activity could accelerate transformation in soil $\mathrm{P}$ fractions. Moreover, SEM results indicated that soil available $\mathrm{P}$ was most related to phosphatase activity and $\mathrm{C}$ composition. Our results contribute to understanding the difference in soil $\mathrm{P}$ pool and $\mathrm{C}$ composition and microorganisms under long-term amendment with straw and its biochar in dry-farming paddy soils.

Acknowledgements This work was funded by Jiangsu Agriculture Science and Technology Innovation Fund (CX(19)1007), the National Natural Science Foundation of China (No. 41671304).
Authors' contributions Conceptualization: SW, YW, XZ. Methodology: JY, HC, GC. Formal analysis and investigation: JY, YW. Original draft preparation: JY. Writing - review and editing: YW, SW. All authors contributed to the study conception and design. All authors read and approved the final manuscript.

Funding Jiangsu Agriculture Science and Technology Innovation Fund (CX(19)1007) the National Natural Science Foundation of China (No. 41671304).

Data availability All data generated or analysed during this study are included in this published article.

\section{Declarations}

Conflict of interest The authors declare that they have no known competing financial interests or personal relationships that could have appeared to influence the work reported in this paper.

Open Access This article is licensed under a Creative Commons Attribution 4.0 International License, which permits use, sharing, adaptation, distribution and reproduction in any medium or format, as long as you give appropriate credit to the original author(s) and the source, provide a link to the Creative Commons licence, and indicate if changes were made. The images or other third party material in this article are included in the article's Creative Commons licence, unless indicated otherwise in a credit line to the material. If material is not included in the article's Creative Commons licence and your intended use is not permitted by statutory regulation or exceeds the permitted use, you will need to obtain permission directly from the copyright holder. To view a copy of this licence, visit http://creativecommons.org/licenses/by/4.0/.

\section{References}

Anderson CR, Condron LM, Clough TJ, Fiers M, Stewart A, Hill RA, Sherlock RR (2011) Biochar induced soil microbial community change: implications for biogeochemical cycling of carbon, nitrogen and phosphorus. Pedobiologia 54:309-320

Ayaz M, Feiziene D, Tilvikiene V, Akhtar K, Stulpinaite U, Iqbal R (2021) Biochar role in the sustainability of agriculture and environment. Sustainability-Basel 13:1

Baldock JA, Masiello CA, Gelinas Y, Hedges JI (2004) Cycling and composition of organic matter in terrestrial and marine ecosystems. Mar Chem 92:39-64

Bi YC, Cai SY, Wang Y, Zhao X, Wang SQ, Xing GX, Zhu ZL (2020) Structural and microbial evidence for different soil carbon sequestration after four-year successive biochar application in two different paddy soils. Chemosphere. 254:1

Biederman LA, Harpole WS (2013) Biochar and its effects on plant productivity and nutrient cycling: a meta-analysis. GCB Bioenergy 5:202-214

Borno ML, Muller-Stover DS, Liu FL (2018) Contrasting effects of biochar on phosphorus dynamics and bioavailability in different soil types. Sci Total Environ 627:963-974

Bowles TM, Acosta-Martínez V, Calderón F, Jackson LE (2014) Soil enzyme activities, microbial communities, and carbon and nitrogen availability in organic agroecosystems across an intensivelymanaged agricultural landscape. Soil Biol Biochem 68:252-262

Chen JH, Chen D, Xu QF, Fuhrmann JJ, Li LQ, Pan GX, Li YF, Qin H, Liang CF, Sun X (2019a) Organic carbon quality, composition of main microbial groups, enzyme activities, and temperature 
sensitivity of soil respiration of an acid paddy soil treated with biochar. Biol Fert Soils 55(2):185-197

Chen WF, Meng J, Han XR, Lan Y, Zhang WM (2019b) Past, present, and future of biochar. Biochar 1:75-87

Chintala R, Schumacher TE, McDonald LM, Clay DE, Malo DD, Papiernik SK, Clay SA, Julson JL (2014) Phosphorus sorption and availability from biochars and soil/biochar mixtures. CLEAN - Soil Air Water 42(5):626-634

Deng SP, Tabatabai MA (1994) Cellulase activity of soils. Soil Biol Biochem 26:1347-1354

Dong XL, Singh BP, Li GT, Lin QM, Zhao XR (2018) Biochar application constrained native soil organic carbon accumulation from wheat residue inputs in a long-term wheat-maize cropping system. Agr Ecosyst Environ 252:200-207

Eivazi F, Tabatabai MA (1988) Glucosidases and galactosidases in soils. Soil Biol Biochem 20:601-606

Frostegard A, Tunlid A, Baath E (1993) Phospholipid fatty-acid composition, biomass, and activity of microbial communities from 2 soil types experimentally exposed to different heavy-metals. Appl Environ Microb 59:3605-3617

Gao S, DeLuca TH, Cleveland CC (2019) Biochar additions alter phosphorus and nitrogen availability in agricultural ecosystems: a meta-analysis. Sci Total Environ 654:463-472

Glaser B, Lehr VI (2019) Biochar effects on phosphorus availability in agricultural soils: a meta-analysis. Sci Rep 9:9338

Guan YS (1986) The determination of soil enzymatic activities: The study method of soil enzyme. China Agriculture Press, China

Guo KY, Zhao YZ, Liu Y, Chen JH, Wu QF, Ruan YF, Li SH, Shi J, Zhao L, Sun X, Liang CF, Xu QF, Qin H (2020) Pyrolysis temperature of biochar affects ecoenzymatic stoichiometry and microbial nutrient-use efficiency in a bamboo forest soil. Geoderma 363:1

Holding AJ (1960) The properties and classification of the predominant gram-negative bacteria occurring in soil. J Appl Bacteriol 23:515-525

Hou EQ, Chen CR, Kuang YW, Zhang YG, Heenan M, Wen DZ (2016) A structural equation model analysis of phosphorus transformations in global unfertilized and uncultivated soils. Global Biogeochem Cy 30:1300-1309

Huang RL, Zhang ZY, Xiao X, Zhang N, Wang XY, Yang ZP, Xu KQ, Liang YT (2019) Structural changes of soil organic matter and the linkage to rhizosphere bacterial communities with biochar amendment in manure fertilized soils. Sci Total Environ 692:333-343

Jiang Y, Qian HY, Huang S, Zhang XY, Wang L, Zhang L, Shen MX, Xiao XP, Chen F, Zhang HL, Lu CY, Li C, Zhang J, Deng AX, van Groenigen KJ, Zhang WJ (2019) Acclimation of methane emissions from rice paddy fields to straw addition. Sci Adv 5:eaau9038

Jin ZW, Chen C, Chen XM, Jiang F, Hopkins I, Zhan XL, Han ZQ, Billy G, Benavides J (2019) Soil acidity, available phosphorus content, and optimal biochar and nitrogen fertilizer application rates: a five-year field trial in upland red soil, China. Field Crop Res 232:77-87

Jing ZW, Chen RR, Wei SP, Feng YZ, Zhang JB, Lin XG (2017) Response and feedback of $\mathrm{C}$ mineralization to $\mathrm{P}$ availability driven by soil microorganisms. Soil Biol Biochem 105:111-120

Jones DL, Edwards AC (1998) Influence of sorption on the biological utilization of two simple carbon substrates. Soil Biol Biochem 30:1895-1902

Leng LJ, Huang HJ, Li H, Li J, Zhou WG (2019) Biochar stability assessment methods: a review. Sci Total Environ 647:210-222

Liang XQ, Jin Y, He MM, Liu Y, Hua GF, Wang S, Tian GM (2017) Composition of phosphorus species and phosphatase activities in a paddy soil treated with manure at varying rates. Agr Ecosyst Environ 237:173-180

Liu SW, Zhang YJ, Zong YJ, Hu ZQ, Wu S, Zhou J, Jin YG, Zou JW (2016) Response of soil carbon dioxide fluxes, soil organic carbon and microbial biomass carbon to biochar amendment: a metaanalysis. Gcb Bioenergy 8:392-406

Liu YL, Ge TD, Zhu ZK, Liu SL, Luo Y, Li Y, Wang P, Gavrichkova O, Xu XL, Xu JK, Wu JS, Guggenberger G, Kuzyakov YO (2019) Carbon input and allocation by rice into paddy soils: a review. Soil Biol Biochem 133:97-107

Lu H, Yan MX, Wong MH, Mo WY, Wang YH, Chen XW, Wang JJ (2020) Effects of biochar on soil microbial community and functional genes of a landfill cover three years after ecological restoration. Sci Total Environ 717:137133

Majumder S, Neogi S, Dutta T, Powel MA, Banik P (2019) The impact of biochar on soil carbon sequestration: Meta-analytical approach to evaluating environmental and economic advantages. J Environ Manage 250:109466

Mitchell PJ, Simpson AJ, Soong R, Simpson MJ (2015) Shifts in microbial community and water-extractable organic matter composition with biochar amendment in a temperate forest soil. Soil Biol Biochem 81:244-254

Montgomery MW, Sgarbieri VC (1975) Isoenzymes of banana polyphenol oxidase. Phytochemistry 14:1245-1249

Murphy J, Riley JP (1962) A modified single solution method for the determination of phosphate in natural waters. Anal Chim Acta 1962(27):31-36

Ng EL, Patti AF, Rose MT, Schefe CR, Wilkinson K, Smernik RJ, Cavagnaro TR (2014) Does the chemical nature of soil carbon drive the structure and functioning of soil microbial communities? Soil Biol Biochem 70:54-61

Ngatia LW, Hsieh YP, Nemours D, Fu R, Taylor RW (2017) Potential phosphorus eutrophication mitigation strategy: biochar carbon composition, thermal stability and $\mathrm{pH}$ influence phosphorus sorption. Chemosphere 180:201-211

Palansooriya KN, Wong JTF, Hashimoto Y, Huang L, Rinklebe J, Chang SX, Bolan N, Wang H, Ok YS (2019) Response of microbial communities to biochar-amended soils: a critical review. Biochar 1:3-22

Pan SY, Dong CD, Su JF, Wang PY, Chen CW, Chang JS, Kim H, Huang CP, Hung CM (2021) The role of biochar in regulating the carbon, phosphorus, and nitrogen cycles exemplified by soil systems. Sustainability-Basel 13:5612

Reed SC, Yang X, Thornton PE (2015) Incorporating phosphorus cycling into global modeling efforts: a worthwhile, tractable endeavor. New Phytol 208:324-329

Richardson AE, Simpson RJ (2011) Soil microorganisms mediating phosphorus availability update on microbial phosphorus. Plant Physiol 156:989-996

Schneider F, Haderlein SB (2016) Potential effects of biochar on the availability of phosphorus - mechanistic insights. Geoderma 277:83-90

Shen DY, Ye CL, Hu ZK, Chen XY, Guo H, Li JY, Du GZ, Adl S, Liu M (2018) Increased chemical stability but decreased physical protection of soil organic carbon in response to nutrient amendment in a Tibetan alpine meadow. Soil Biol Biochem 126:11-21

Shrestha BM, Singh BR, Forte C, Certini G, de Varennes A (2015) Long-term effects of tillage, nutrient application and crop rotation on soil organic matter quality assessed by NMR spectroscopy. Soil Use Manage 31:358-366

Sinsabaugh RL (2010) Phenol oxidase, peroxidase and organic matter dynamics of soil. Soil Biol Biochem 42:391-404

Tabatabai MA (1994) Soil enzymes. Methods of soil analysis: Part 2-Microbiological and Biochemical Properties. 775-833

Tiessen H, Moir JO (1993) Characterization of available P by sequential extraction. Can J Soil Sci

Uchimiya M, Hiradate S, Antal MJ (2015) Dissolved phosphorus speciation of flash carbonization, slow pyrolysis, and fast pyrolysis biochars. Acs Sustain Chem Eng 3:1642-1649 
Wang Y, Zhao X, Wang L, Zhao PH, Zhu WB, Wang SQ (2016) Phosphorus fertilization to the wheat-growing season only in a ricewheat rotation in the Taihu Lake region of China. Field Crop Res 198:32-39

Wang HY, Nie Y, Butterly CR, Wang L, Chen Q, Tian W, Song BB, Xi YG, Wang Y (2017) Fertilization alters microbial community composition and functional patterns by changing the chemical nature of soil organic carbon: a field study in a Halosol. Geoderma 292:17-24

Wei XM, Razavi BS, Hu YJ, Xu XL, Zhu ZK, Liu YH, Kuzyakov Y, Li., Wu JS, Ge TD, (2019) C/P stoichiometry of dying rice root defines the spatial distribution and dynamics of enzyme activities in root-detritusphere. Biol Fert Soils 55:251-263

Xu G, Sun J, Shao H, Chang SX (2014) Biochar had effects on phosphorus sorption and desorption in three soils with differing acidity. Ecol Eng 62:54-60

Xu G, Shao HB, Zhang Y, Junna S (2018) Nonadditive effects of biochar amendments on soil phosphorus fractions in two contrasting soils. Land Degrad Dev 29:2720-2727

Xu LY, Wang MY, Tian YT, Shi XZ, Shi YJ, Yu QB, Xu SX, Pan JH, Li XW, Xie XQ (2020) Relationship between macropores and soil organic carbon fractions under long-term organic manure application. Land Degrad Dev 31:1344-1354

Yang L, Wu YC, Wang YC, An WQ, Jin J, Sun K, Wang XK (2021) Effects of biochar addition on the abundance, speciation, availability, and leaching loss of soil phosphorus. Sci Total Environ $758: 143657$
Yuan HZ, Zhu ZK, Wei XM, Liu SL, Peng PQ, Gunina A, Shen JL, Kuzyakov Y, Ge TD, Wu JS, Wang JR (2019) Straw and biochar strongly affect functional diversity of microbial metabolism in paddy soils. J Integr Agr 18:1474-1485

Zelles L (1999) Fatty acid patterns of phospholipids and lipopolysaccharides in the characterisation of microbial communities in soil: a review. Biol Fert Soils 29:111-129

Zhai LM, Caiji ZM, Liu J, Wang HY, Ren TZ, Gai XP, Xi B, Liu HB (2015) Short-term effects of maize residue biochar on phosphorus availability in two soils with different phosphorus sorption capacities. Biol Fert Soils 51:113-122

Zhang JJ, Wei YX, Liu JZ, Yuan JC, Liang Y, Ren J, Cai HG (2019) Effects of maize straw and its biochar application on organic and humic carbon in water-stable aggregates of a Mollisol in Northeast China: A five-year field experiment. Soil till Res 190:1-9

Zhang QQ, Song YF, Wu Z, Yan XY, Gunina A, Kuzyakov Y, Xiong ZQ (2020) Effects of six-year biochar amendment on soil aggregation, crop growth, and nitrogen and phosphorus use efficiencies in a rice-wheat rotation. J Clean Prod 242:118435

Zhao X, Wang J, Wang SQ, Xing GX (2014) Successive straw biochar application as a strategy to sequester carbon and improve fertility: a pot experiment with two rice/wheat rotations in paddy soil. Plant Soil 378(1-2):279-294

Zhou CF, Heal K, Tigabu M, Xia LD, Hu HY, Yin DY, Ma XQ (2020) Biochar addition to forest plantation soil enhances phosphorus availability and soil bacterial community diversity. Forest Ecol Manag 455:117635 